\title{
First Example of Direct Transformation of Alkylbenzenes to 1,3-Benzodioxoles by Oxidation with $o$-Chloranil.
}

\section{Sheikh Maksudur Rahman and Tomoshige Kobayashi*}

Department of Chemistry, Faculty of Science, Shinshu University, 3-1-1 Asahi, Matsumoto 390-8621, Japan. Tel. +81-263-37-2470, Fax +81-263-37-2470

* Author to whom correspondence should be addressed; e-mail: tkobaya@gipac.shinshu-u.ac.jp

Received: 23 March 2002; in revised form: 5 November 2002 / Accepted: 7 November 2002 /

Published: 30 November 2002

Abstract: The reaction of alkyl-substituted benzenes with $o$-chloranil at an elevated temperature was found to give 4,5,6,7-tetrachloro-1,3-benzodioxoles via benzylic oxidation and subsequent acetal formation, albeit in poor yields.

Keywords: Oxidation, 1,3-Benzodioxole, $o$-Chloranil

\section{Introduction}

The oxidation of benzylic positions to carbonyl groups is one of the most important transformations in the synthetic chemistry [1,2]. On the other hand, if the transformation of benzylic positions directly into acetals as depicted in Scheme 1 were realized, it would be also useful in organic synthesis.

\section{Scheme 1}

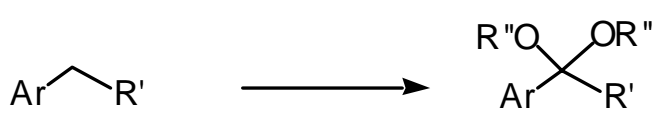


During the course of our studies aimed at synthesis of a bicyclo[2.2.2]oct-5-ene-2,3-dione skeleton by the Diels-Alder reaction of 2,3,4,5-tetrachloro-o-benzoquinone (o-chloranil, 3 ) and dienophiles in refluxing toluene $[3,4]$, we eventually found that $o$-chloranil reacted with toluene to afford a 1,3-benzodioxole derivative. Through an extensive search for literature precedents, an example of a similar transformation was found [5-8]. Ansell and Bignold described that the reaction of $o$-chloranil (3) with 2,5-dimethyl-2,4-hexadiene at $0^{\circ} \mathrm{C}$ provided the benzodioxole $\mathbf{4}$ in good yield (83\%) by the oxidation of the allylic position and a subsequent acetal formation [8]. However, similar treatment of $\mathbf{3}$ with 2,3-dimethyl-2-butene was reported to give the 1,4-benzodioxane derivatives $\mathbf{5}$ and $\mathbf{6}$, and no evidence for the formation of a 1,3-benzodioxole was observed [9]. Thus, the structural requirements necessary for the dioxole formation were ambiguous. A similar oxidative formation of dioxoles has been described for the reaction of 1-tetralones with $\mathbf{3}$, which gave cyclic diethers at the $\alpha$-position of the carbonyl group [10,11]. The formation of dioxoles has also been reported for the photochemical reactions of $o$-quinones with an isobenzofuran [12] and some alkenes [13], the thermal reactions of $o$ quinones with diazo compounds $[14,15,16]$, and the reactions of $o$-chloranil with phosphorus ylides $[17,18]$. However, the formation of 1,3-benzodioxoles by a benzylic oxidation of alkyl-substituted benzenes with $o$-quinones has not been reported, to the best of our knowledge. With the background as described above, we wish to report here the scope and limitations for the formation of 1,3benzodioxoles by a novel benzylic oxidation with $o$-chloranil (3).

\section{Scheme 2}

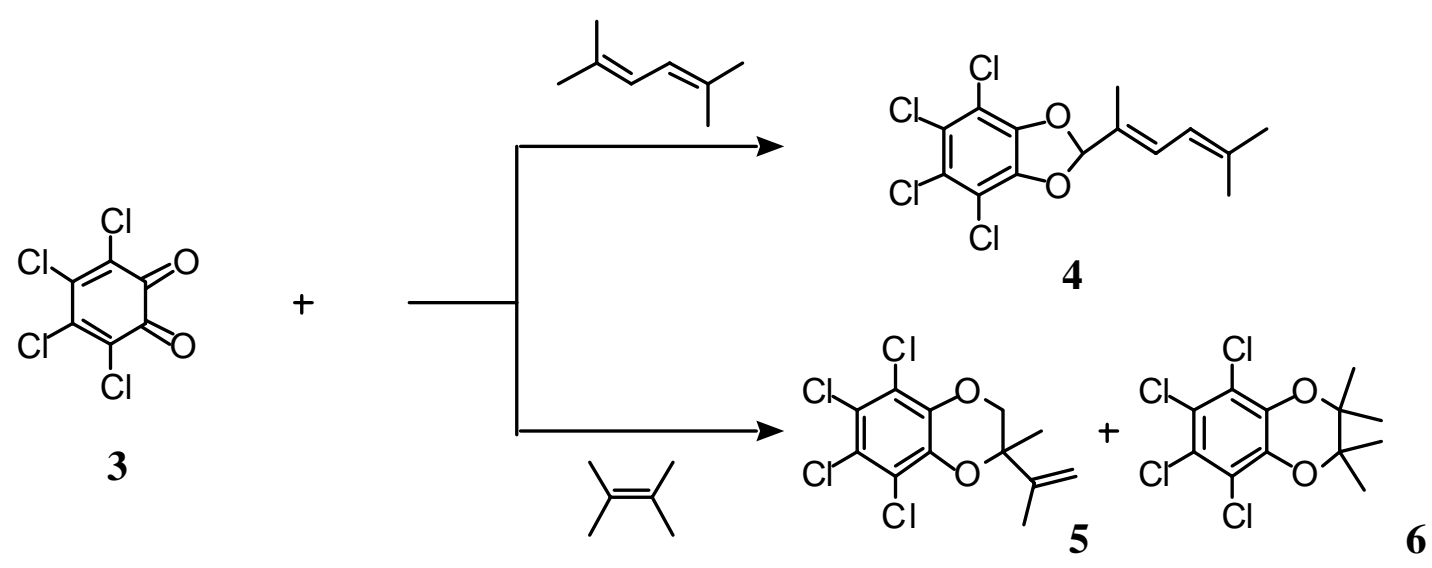

\section{Results and Discussion}

When $o$-chloranil (3) was heated in toluene (7) under reflux, 4,5,6,7-tetrachloro-2-phenyl-1,3benzodioxole (13) was obtained. The same reaction at $80^{\circ} \mathrm{C}$ resulted in the recovery of 3 , and thus a temperature around that of refluxing toluene seems to be necessary for the present transformation. The GLC analysis of the reaction mixture indicated the simultaneous formation of tetrachlorocatechol (19). The yield of $\mathbf{1 3}$ was rather poor (21\%, see Table 1$)$ in contrast to that of allylic oxidation with $\mathbf{3}$ as 
described above, but we could not isolate other products whose structures can be determined. The reaction of diphenylmethane (8) with two molar equivalent amounts of $\mathbf{3}$ in refluxing tetrachloroethylene provided 4,5,6,7-tetrachloro-2,2-diphenyl-1,3-benzodioxole (14) in 26\% yield along with the formation of 19. These results are in contrast to those for the oxidation reaction of $\mathbf{8}$ with $3,33^{\prime}, 5,5^{\prime}-$ tetra-t-butyldiphenoquinone at $260^{\circ} \mathrm{C}$, which was reported to provide a dimeric product, 1,1,2,2-tetraphenylethane [19]. When an equimolar amount or three molar equivalents of $\mathbf{3}$ was employed in the present reaction, the yield of $\mathbf{1 4}$ decreased to $16 \%$ or $21 \%$, respectively. Similar reactions of mesitylene (9) and durene (10) afforded the 1,3-benzodioxoles 15 and 16, respectively. For these compounds, the use of a large excess amount of $\mathbf{3}$ did not afford other products by the further oxidation of other methyl groups. On the other hand, the reaction of $p$-xylene (11) with two molar equivalent amounts of $\mathbf{3}$ resulted in the formation of a complex mixture, from which we could obtain no evidence for the formation of the corresponding 1,3-benzodioxole. However, the use of four molar equivalent amounts of $\mathbf{3}$ resulted in the formation of 4,5,6,7-tetrachloro-2-(2,5-dimethylphenyl)-2-(4methylphenyl)-1,3-benzodioxole (17). In contrast to the results described above, the reaction of indane (12) with 3 gave the benzodioxane derivative 18 instead of the presumed benzodioxole derivative. The reactions of 4-methylanisole and $N, N$-dimethyl-p-toluidine with $\mathbf{3}$ gave complex mixtures, while those of 4-nitrotoluene and $p$-tolunitrile resulted in the recovery of the starting materials: the dioxole formation seems to be sensitive to the electronic effects of substituents.

Scheme 3.

$3+\mathrm{ArCH}_{2} \mathrm{R}$ or

$7-11$<smiles>Cc1ccc(C2(c3ccc(C)cc3C)Oc3c(Cl)c(Cl)c(Cl)c(Cl)c3O2)cc1</smiles>

17
12<smiles>c1ccc2c(c1)CCC2</smiles><smiles>[R]C1([123I])Oc2c(Cl)c(Cl)c(Cl)c(Cl)c2O1</smiles>

13: $\mathrm{Ar}=\mathrm{Ph}, \mathrm{R}=\mathrm{H}$

14: $\mathrm{Ar}=\mathrm{R}=\mathrm{Ph}$

15: $\mathrm{Ar}=3,5-\mathrm{Me}_{2} \mathrm{C}_{6} \mathrm{H}_{3}, \mathrm{R}=\mathrm{H}$

16: $\mathrm{Ar}=2,4,5-\mathrm{Me}_{3} \mathrm{C}_{6} \mathrm{H}_{2}, \mathrm{R}=\mathrm{H}$<smiles>Clc1c(Cl)c(Cl)c2c(c1Cl)OC1Cc3ccccc3C1O2</smiles>

18<smiles>Oc1c(Cl)c(O)c(Cl)c(Cl)c1Cl</smiles>

19 
Table 1. The reactions of alkyl benzenes with $o$-chloranil (3) under reflux conditions.

\begin{tabular}{lccl}
\hline \multicolumn{1}{c}{ Substrate } & Solvent & Time $(\mathrm{h})$ & \multicolumn{1}{c}{ Products (Yield) } \\
\hline toluene (7) & toluene & 24 & $\mathbf{1 3}(\mathrm{Ar}=\mathrm{Ph}, \mathrm{R}=\mathrm{H} ; 21 \%), \mathbf{1 9}(8 \%)$ \\
diphenylmethane $(\mathbf{8})$ & $\mathrm{Cl}_{2} \mathrm{C}=\mathrm{CCl}_{2}$ & 48 & $\mathbf{1 4}(\mathrm{Ar}=\mathrm{R}=\mathrm{Ph} ; 26 \%), \mathbf{1 9}(3 \%)$ \\
mesitylene (9) & $\mathrm{Cl}_{2} \mathrm{C}=\mathrm{CCl}_{2}$ & 48 & $\mathbf{1 5}\left(\mathrm{Ar}=3,5-\mathrm{Me}_{2} \mathrm{C}_{6} \mathrm{H}_{3}, \mathrm{R}=\mathrm{H} ; 8 \%\right), \mathbf{1 9}(16 \%)$ \\
durene (10) & $\mathrm{Cl}_{2} \mathrm{C}=\mathrm{CCl}_{2}$ & 24 & $\mathbf{1 6}\left(\mathrm{Ar}=2,4,5-\mathrm{Me}_{3} \mathrm{C}_{6} \mathrm{H}_{2} ; \mathrm{R}=\mathrm{H} ; 3 \%\right), \mathbf{1 9}(59 \%)$ \\
p-xylene (11) & $\mathrm{Cl}_{2} \mathrm{C}=\mathrm{CCl}_{2}$ & 36 & $\mathbf{1 7}(14 \%), \mathbf{1 9}(17 \%)$ \\
indane (12) & $\mathrm{Cl}_{2} \mathrm{C}=\mathrm{CCl}_{2}$ & 24 & $\mathbf{1 8}(5 \%), \mathbf{1 9}(60 \%)$ \\
\hline
\end{tabular}

A plausible mechanism for the reported reaction is shown in Scheme 4. Dehydrogenation reactions with quinones have been reported to involve carbenium ions, although electron transfer reactions leading to radical species could also intervene [5]. In the present reaction, an ion pair 20 formed by abstraction of a hydride from the benzylic position by $o$-chloranil (3) would undergo the combination leading to $\mathbf{2 1}$. The reactions of 2,3-dichloro-5,6-dicyano-p-benzoquinone (DDQ) with methyl-substituted benzenes have been reported to give ethers formed by combination of these substrates [20]. The further oxidation of $\mathbf{2 1}$ by $\mathbf{3}$ would give the cation $\mathbf{2 2}$, and the subsequent intramolecular cyclization of $\mathbf{2 2}$ would provide the 1,3-benzodioxoles. In the reaction with $p$-xylene, the hydride-abstraction at the 2-position of an initially formed benzodioxole by $\mathbf{3}$ would give the 1,3benzodixolium ion $\mathbf{2 3}$ [21,22], which would undergo the Friedel-Crafts type reaction with $p$-xylene to provide 17. The reaction of indane with 3 would undergo dehydrogenation leading to indene (24), and the Diels-Alder reaction of $\mathbf{2 4}$ and $\mathbf{3}$ would afford $\mathbf{1 8}$. The dehydrogenation or Diels-Alder reactions with $\mathbf{3}$ have been well recognized [5]. In fact, when indene (24) was treated with $\mathbf{3}$ in refluxing tetrachloroethylene, the Diels-Alder adduct $\mathbf{1 8}$ was obtained albeit in low yield.

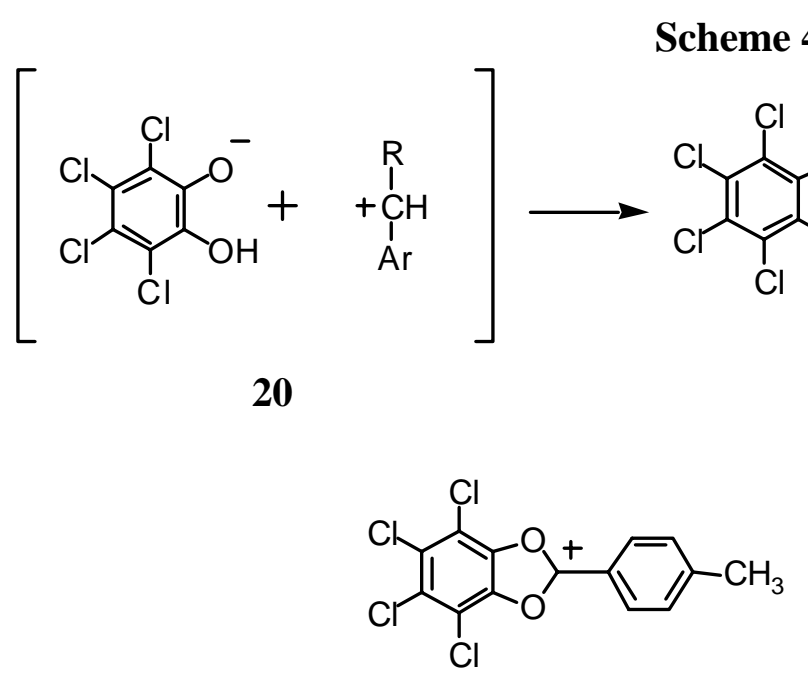

23<smiles>C1=Cc2ccccc2C1</smiles> 


\section{Conclusions}

In conclusion, the reactions of alkyl-substituted benzenes with $o$-chloranil (3) were found to produce 1,3-benzodioxoles albeit in poor yields. Previously, the acetal formation of carbonyl compounds with catechols has been employed for the syntheses of 1,3-benzodioxoles [23]. Although the benzodioxoles $\mathbf{1 3}$ and $\mathbf{1 4}$ have been already reported by the reaction of $o$-chloranil with diazomethanes [15,16] or benzylidenephosphorane [17], the present reaction may open up a new pathway to prepare 4,5,6,7-tetrachloro-1,3-benzodioxoles, as well as a new type of transformation of benzylic positions into acetals. 1,3-Benzodioxoles have been reported to possess a various type of biological activities and to be useful as antitumor drugs and elndothelin receptor antagonists [24,25]: those of tetrachloro-substituted benzodioxoles may be also of interest.

\section{Experimental}

\section{General}

All mps were determined with a Yanagimoto hot-stage apparatus. IR spectra were obtained with a JEOL Diamond-20 spectrometer. NMR spectra were recorded with a JEOL JNM-LA400 ( ${ }^{1} \mathrm{H}: 400$ $\mathrm{MHz},{ }^{13} \mathrm{C}$ : $100 \mathrm{MHz}$ ) spectrometer using TMS as internal standard. Assignments of the ${ }^{1} \mathrm{H}-$ and ${ }^{13} \mathrm{C}-\mathrm{NMR}$ signals are based on DEPT, H-H COSY, and C-H COSY measurements. Mass spectra were measured with a Shimadzu GCMS-QP1000EX spectrometer operating in the electron impact mode (70 eV). Elemental analyses were performed with a Perkin-Elmer Model 240 apparatus. The GLC analyses were carried out on a Shimadzu GC-12A (FID) instrument equipped with a 10\%-SE30 column at 180 ${ }^{\circ} \mathrm{C}$ column temperature using nitrogen as the carrier gas. Solvents were dried and purified by standards methods. Yields are based on the isolated products with sufficient purity.

\section{A General Procedure for the Reactions of Alkyl-Substituted Benzenes and o-Chloranil.}

A solution of $o$-chloranil $3(2.46 \mathrm{~g}, 10 \mathrm{mmol})$ and a substituted benzene derivative $(5 \mathrm{mmol})$ in tetrachloroethylene $(10 \mathrm{~mL})$ was refluxed for a period as shown in Table 1. The mixture was concentrated and the residue was separated by column chromatography (silica gel, hexane-benzene 10/1). The fractionated solution was concentrated and the resulting solid was collected by suction to give the product with the yield listed in Table 1. The yields of the products are based on the assumption that it is necessary to use two molar equivalents of $o$-chloranil $\mathbf{3}$ for the formation of the dioxoles. In the case with the reaction of toluene, a solution of $o$-chloranil $3(10 \mathrm{mmol})$ in toluene $(10 \mathrm{~mL})$ was refluxed. In the reaction with $p$-xylene, $4.92 \mathrm{~g}(20 \mathrm{mmol})$ of $o$-chloranil was employed. The remaining parts of the fractions after chromatography and the filtrate were collected, and the yield of tetrachlorocatechol (19) was determined with GLC analyses with benzophenone as an internal standard. 
4,5,6,7-Tetetrachloro-2-phenyl-1,3-benzodioxole (13): 21\%; colorless needles (from methanol); mp 114-115 ${ }^{\circ} \mathrm{C}$ (lit [15] mp $119{ }^{\circ} \mathrm{C}$ ); IR (KBr) 3070, 3055, 3041, 2945, 1604, 1466, 1452, 1379, 1327 , 1302, 1227, 1043, $1024 \mathrm{~cm}^{-1} ;{ }^{1} \mathrm{H}-\mathrm{NMR}\left(\mathrm{CDCl}_{3}\right) \delta=7.18(1 \mathrm{H}, \mathrm{s}, 2-\mathrm{H}), 7.51(5 \mathrm{H}, \mathrm{m}, \mathrm{Ph}) ;{ }^{13} \mathrm{C}-\mathrm{NMR}$ $\left(\mathrm{CDCl}_{3}\right) \delta=112.9(\mathrm{C}-4$ and $\mathrm{C}-7), 113.0(\mathrm{C}-2), 125.4,126.5,128.9,131.2,133.9,144.4 ; \mathrm{MS} \mathrm{m} / \mathrm{z}$ (rel intensity) 334/336/338/340 $\left(\mathrm{M}^{+}, 71 / 100 / 45 / 11\right), 299 / 301 / 303 / 305(\mathrm{M}-\mathrm{Cl}, 42 / 24 / 14 / 5)$, 257/259/261/263 (M - Ph, 18/24/12/3), 105 (PhCO, 86), 77 (Ph, 79). Found: C, 46.28; H, 1.92\%. Calcd for $\mathrm{C}_{13} \mathrm{H}_{6} \mathrm{Cl}_{4} \mathrm{O}_{2}$ : C, 46.47; H, $1.80 \%$.

4,5,6,7-Tetrachloro-2,2-diphenyl-1,3-benzodioxole (14): 26\%; colorless prisms (from chloroformmethanol 1/1); mp 152-153 ${ }^{\circ} \mathrm{C}$ (lit [16] mp $141{ }^{\circ} \mathrm{C}$ ); IR (KBr) 3093, 3066, 3032, 1655, 1495, 1450, 1379, 1304, 1263, 1227, 1211, 1178, 1157, 1043, 1020, $1004 \mathrm{~cm}^{-1} ;{ }^{1} \mathrm{H}-\mathrm{NMR}\left(\mathrm{CDCl}_{3}\right) \delta=7.41(6 \mathrm{H}, \mathrm{m})$, $7.57(4 \mathrm{H}, \mathrm{m}) ;{ }^{13} \mathrm{C}-\mathrm{NMR}\left(\mathrm{CDCl}_{3}\right) \delta=113.1(\mathrm{C}-4$ and $\mathrm{C}-7), 120.5(\mathrm{C}-2), 125.3,126.3,128.5,129.9$, 138.2, 144.0; $\mathrm{MS} m / z$ (rel intensity) 410/412/414/416 $\left(\mathrm{M}^{+}, 57 / 70 / 35 / 9\right), 375 / 377 / 379(\mathrm{M}-\mathrm{Cl}$, 83/80/27), 333/335/337/339 (M - Ph, 47/64/31/9), 165 ( $\left.\mathrm{Ph}_{2} \mathrm{C}-\mathrm{H}, 100\right), 105$ (PhCO, 94), 77 (Ph, 49). Found: C, 55.67; H, 2.41\%. Calcd for $\mathrm{C}_{19} \mathrm{H}_{10} \mathrm{Cl}_{4} \mathrm{O}_{2}$ : C, 55.38; H, 2.45\%.

4,5,6,7-Tetrachloro-2-(3,5-dimethylphenyl)-1,3-benzodioxole (15): 8\%; colorless needles (from chloroform-methanol 2/1); 159.5-160 ${ }^{\circ} \mathrm{C}$; IR (KBr) 3012, 2918, 2856, 1616, 1603, 1506, 1462, 1377 , 1321, 1304, 1286, 1267, 1236, 1227, 1169, 1066, $1014 \mathrm{~cm}^{-1} ;{ }^{1} \mathrm{H}-\mathrm{NMR}\left(\mathrm{CDCl}_{3}\right) \delta=2.36\left(6 \mathrm{H}, \mathrm{s}, \mathrm{CH}_{3}\right)$, $7.09(1 \mathrm{H}, \mathrm{s}, 2-\mathrm{H}), 7.12(1 \mathrm{H}, \mathrm{s}), 7.16(2 \mathrm{H}, \mathrm{s}) ;{ }^{13} \mathrm{C}-\mathrm{NMR}\left(\mathrm{CDCl}_{3}\right) \delta=21.3\left(\mathrm{CH}_{3}\right), 112.8(\mathrm{C}-4$ and $\mathrm{C}-7)$, 113.4 (C-2), 124.2, 125.2, 132.8, 133.7, 138.8, 144.5; MS m/z (rel intensity) 362/364/366/368 (M+, 78/100/49/12), 327/329/331 (M - Cl, 62/57/21), 133 ( $\left.\mathrm{Me}_{2} \mathrm{C}_{6} \mathrm{H}_{3} \mathrm{CO}, 44\right), 105$ (PhCO, 40), 77 (Ph, 38). Found: C, 49.43; H, 2.77\%. Calcd for $\mathrm{C}_{15} \mathrm{H}_{10} \mathrm{Cl}_{4} \mathrm{O}_{2}$ : C, 49.49; $\mathrm{H}, 2.77 \%$.

4,5,6,7-Tetrachloro-2-(2,4,5-trimethylphenyl)-1,3-benzodioxole (16): 3\%; colorless needles (from chloroform-methanol 1/1); 187-188 ${ }^{\circ} \mathrm{C}$; IR (KBr) 2970, 2937, 2920, 2864, 1506, 1456, 1389, 1381, 1320, 1304, 1286, 1269, 1238, 1225, 1201, 1088, $1016 \mathrm{~cm}^{-1} ;{ }^{1} \mathrm{H}-\mathrm{NMR}\left(\mathrm{CDCl}_{3}\right) \delta=2.25\left(3 \mathrm{H}, \mathrm{s}, \mathrm{CH}_{3}\right)$, $2.26\left(3 \mathrm{H}, \mathrm{s}, \mathrm{CH}_{3}\right), 2.38\left(3 \mathrm{H}, \mathrm{s}, \mathrm{CH}_{3}\right), 7.04(1 \mathrm{H}, \mathrm{s}, 2-\mathrm{H}), 7.27(1 \mathrm{H}, \mathrm{s}), 7.28(1 \mathrm{H}, \mathrm{s}) ;{ }^{13} \mathrm{C}-\mathrm{NMR}\left(\mathrm{CDCl}_{3}\right)$ $\delta=18.2\left(\mathrm{CH}_{3}\right), 19.3\left(\mathrm{CH}_{3}\right), 19.6\left(\mathrm{CH}_{3}\right), 112.4(\mathrm{C}-2), 112.8(\mathrm{C}-4$ and $\mathrm{C}-7), 125.1,127.7,128.7,132.6$, 134.2, 134.5, 139.7, 144.5; MS $m / z$ (rel intensity) 376/378/380/382 $\left(\mathrm{M}^{+}, 81 / 100 / 51 / 12\right), 341 / 343 / 345$ ( $\mathrm{M}$ - Cl, 49/48/16), $147\left(\mathrm{Me}_{3} \mathrm{C}_{6} \mathrm{H}_{2} \mathrm{CO}, 65\right), 119\left(\mathrm{Me}_{3} \mathrm{C}_{6} \mathrm{H}_{2}, 48\right), 105$ (PhCO, 25), 77 (Ph, 30). Found: C, 50.92; H, 3.15\%. Calcd for $\mathrm{C}_{16} \mathrm{H}_{12} \mathrm{Cl}_{4} \mathrm{O}_{2}$ : C, 50.83; H, 3.20\%.

4,5,6,7-Tetrachloro-2-(2,5-dimethylphenyl)-2-(4-methylphenyl)-1,3-benzodioxole (17): 14\%; colorless prisms (from hexane); mp 132-133 ${ }^{\circ} \mathrm{C}$; IR (KBr) 3030, 2966, 2922, 2868, 1612, 1512, 1496, 1448, 1381, 1309, 1294, 1265, 1236, 1163, 1032, 1016, $1007 \mathrm{~cm}^{-1} ;{ }^{1} \mathrm{H}-\mathrm{NMR}\left(\mathrm{CDCl}_{3}\right) \delta=2.18\left(3 \mathrm{H}, \mathrm{s}, \mathrm{CH}_{3}\right)$, $2.37\left(6 \mathrm{H}, \mathrm{s}, \mathrm{CH}_{3}\right), 7.08(1 \mathrm{H}, \mathrm{d}, J=8 \mathrm{~Hz}),, 7.13(1 \mathrm{H}, \mathrm{d}, J=8 \mathrm{~Hz}), 7.18(2 \mathrm{H}, \mathrm{d}, J=8 \mathrm{~Hz}), 7.33(2 \mathrm{H}, \mathrm{d}, J=8$ 
$\mathrm{Hz}), 7.56(1 \mathrm{H}, \mathrm{s}) ;{ }^{13} \mathrm{C}-\mathrm{NMR}\left(\mathrm{CDCl}_{3}\right) \delta=20.3\left(\mathrm{CH}_{3}\right), 21.2\left(\mathrm{CH}_{3}\right), 21.3\left(\mathrm{CH}_{3}\right), 112.9(\mathrm{C}-4$ and $\mathrm{C}-7)$, 121.6 (C-2), 125.0, 126.6, 127.1, 129.2, 130.6, 132.2, 133.8, 134.6, 135.1, 135.5, 140.2, 144.0; $\mathrm{MS} \mathrm{m} / \mathrm{z}$ (rel intensity) 452/454/456/458 $\left(\mathrm{M}^{+}, 38 / 49 / 24 / 6\right), 437 / 439 / 441 / 443\left(\mathrm{M}-\mathrm{CH}_{3}, 81 / 100 / 52 / 13\right)$, 417/419/421 (M - Cl, 43/38/14), 207 (M - 3- H, 29), 192 (m/z $\left.207-\mathrm{CH}_{3}, 65\right), 178$ (m/z $207-\mathrm{Me}_{2}$, 55), $133\left(\mathrm{Me}_{2} \mathrm{C}_{6} \mathrm{H}_{3} \mathrm{CO}, 21\right), 105$ (PhCO, 14), 77 (Ph, 12). Found: C, 58.24; H, 3.55\%. Calcd for $\mathrm{C}_{22} \mathrm{H}_{16} \mathrm{Cl}_{4} \mathrm{O}_{2}$ : C, 58.18; H, 3.55\%.

6,7,8,9-Tetrachloro-10a,11-dihydro-4bH-5,10-dioxabenzo[b]fluorene (18): 5\%; colorless needles (from chloroform-methanol 1/1) ; mp $158-159.5{ }^{\circ} \mathrm{C}$; IR (KBr) 2951, 1560, 1473, 1460, 1431, 1425, 1398, 1351, 1334, 1281, 1261, 1157, 1103, 1074, 1047, $1016 \mathrm{~cm}^{-1} ;{ }^{1} \mathrm{H}-\mathrm{NMR}\left(\mathrm{CDCl}_{3}\right) \delta=3.29(2 \mathrm{H}, \mathrm{d}$, $J=4 \mathrm{~Hz}, 11-\mathrm{H}), 4.99(1 \mathrm{H}, \mathrm{q}, J=4 \mathrm{~Hz}, 10-\mathrm{H}), 5.66(1 \mathrm{H}, \mathrm{d}, J=4 \mathrm{~Hz}, 4 \mathrm{~b}-\mathrm{H}), 7.32(3 \mathrm{H}, \mathrm{m}), 7.47$ (1H, d, $J=7$ $\mathrm{Hz}) ;{ }^{13} \mathrm{C}-\mathrm{NMR}\left(\mathrm{CDCl}_{3}\right) \delta=36.8(\mathrm{C}-11), 76.1$ (C-10a), $78.4(\mathrm{C}-4 \mathrm{~b}), 120.3,120.7,124.3,124.7,125.9$, 127.7, 129.9, 137.8, 138.7, 139.1, 139.5, 1C missing; MS m/z (rel intensity) 360/362/364/366 ( $\mathrm{M}^{+}$, 21/26/13/3), $116(\mathbf{2 4}, 100), 115$ (24 - H, 91). Found: C, 49.50; H, 2.15\%. Calcd for $\mathrm{C}_{15} \mathrm{H}_{8} \mathrm{Cl}_{4} \mathrm{O}_{2}$ : C, $49.76 ; \mathrm{H}, 2.23 \%$.

The Reaction of Indene (24) with o-Chloranil 3. A solution of indene (24) (581 $\mathrm{mg}, 5 \mathrm{mmol}$ ) and $o$ chloranil 3 (1.23 g, $5 \mathrm{mmol})$ in tetrachloroethylene $(10 \mathrm{~mL})$ was refluxed for $24 \mathrm{~h}$. The mixture was concentrated and the residue was separated by column chromatography (silica gel, hexane-benzene 5/1) to give $\mathbf{1 8}$ (212 $\mathrm{mg}, 12 \%)$ : $\mathrm{mp}$ and mixed $\mathrm{mp} 156-157^{\circ} \mathrm{C}$.

\section{References and Notes}

1. Larock, R. C. Comprehensive Organic Transformations, VCH Publishers, New York, 1989, pp 591-592.

2. Nicolaou, K. C.; Baran, P. S.; Zhong, Y.-L. J. Am. Chem. Soc., 2001, 123, 3183, and references cited therein.

3. Kobayashi, S.; Rahman, S. M.; Kobayashi, T. Unpublished results from our laboratory.

4. Kobayashi, T.; Kobayashi, S. Eur. J. Org. Chem., 2002, in submission.

5. Becker, H.-D. "Quinones as oxidants and dehydrogenating agents" in The chemistry of the quinonoid compounds Part 1, ed. Patai, S.; John Wiley \& Sons; London, New York, Sydney, and Toronto, 1974, Chapter 7, pp 335-423.

6. Walker, D.; Hiebert, J. D. Chem. Rev., 1967, 67, 153.

7. Jackman, L. M. Adv. Org. Chem., 1960, 2, 329.

8. Ansell, M. F.; Bignold, A. J. Chem. Commun., 1969, 1096.

9. Ansell, M. F.; Bignold, A. J. Chem. Commun., 1970, 989.

10. Kasturi, T. R.; Arunachalam, T. Can. J. Chem., 1968, 46, 3625.

11. Kasturi, T. R.; Arunachalam, T.; Subrahmanyam, G. J. Chem. Soc. (C), 1970, 1257. 
12. Friedrichsen, W. Tetrahedron Lett., 1969, 1219.

13. Farid, S.; Hess, D.; Pfundt, G.; Schloz, K.-H.; Steffan, G. Chem. Commun., 1968, 638.

14. Horspool, W. M. Quart. Rev., 1969, 23, 204.

15. Schönberg, A.; Schütz, G. Chem. Ber., 1962, 95, 2386.

16. Schönberg, A.; Awad, W. I.; Latif, N. J. Chem. Soc., 1951, 1368.

17. Bestmann, H. J.; Lang, H. J. Tetrahedron Lett., 1969, 2101.

18. Cardillo, G.; Merlini, L.; Servi, S. Ann. Chim. (Rome), 1970, 60, 564.

19. Hay, A. S. Tetrahedron Lett., 1965, 4241.

20. Foster, R.; Horman, I. J. Chem. Soc. (B), 1966, 1049.

21. Pittman, Jr., C. U.; McManus, S. P.; Larsen, J. W. Chem. Rev., 1972, 72, 357.

22. Olah, G. A.; Grant, J. L. J. Org. Chem., 1977, 42, 2237.

23. Cole, E. R.; Crank, G.; Hai Minh, H. T. Aust. J. Chem., 1980, 33, 675; and references cited therein.

24. Fukuto, T. R.; Keadtisuke, S. Ration. Approaches Struct., Act., Ecotoxicol. Agrochem., ed. Draber, W.; Fujita, T., CRC, Boca Raton, Fla, 1992, pp 163-183.

25. Bakhite, E. A.; Radwan, Sh. M. Pharmazie, 1999, 54, 491.

Samples Availability: Available from MDPI.

(C) 2002 by MDPI (http://www.mdpi.org). Reproduction is permitted for noncommercial purposes. 